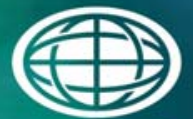

Savannah River

National Laboratory ${ }^{\mathrm{m}}$

OPERATED BY SAVANNAH RIVER NUCLEAR SOLUTIONS

\title{
Characterization of the Tank 51 Alternate Reductant Sludge Batch 9 Slurry Sample
} (HTF-51-15-130)

S. H. Reboul

February 2016

SRNL-STT-2016-00065, Revision 0 


\section{DISCLAIMER}

This work was prepared under an agreement with and funded by the U.S. Government. Neither the U.S. Government or its employees, nor any of its contractors, subcontractors or their employees, makes any express or implied:

1. warranty or assumes any legal liability for the accuracy, completeness, or for the use or results of such use of any information, product, or process disclosed; or

2. representation that such use or results of such use would not infringe privately owned rights; or

3. endorsement or recommendation of any specifically identified commercial product, process, or service.

Any views and opinions of authors expressed in this work do not necessarily state or reflect those of the United States Government, or its contractors, or subcontractors.

\section{Printed in the United States of America \\ Prepared for U.S. Department of Energy}


Keywords: Tank 51, Sludge Batch 9, Alternate Reductant, Characterization

Retention: Permanent

\section{Characterization of the Tank 51 Alternate Reductant Sludge Batch 9 Slurry Sample (HTF-51-15-130)}

S. H. Reboul

February 2016

Prepared for the U.S. Department of Energy under contract number DE-AC09-08SR22470. 


\section{REVIEWS AND APPROVALS}

AUTHOR:

S. H. Reboul, Advanced Characterization and Processing

Date

TECHNICAL REVIEW:

C. J. Martino, Process Technology Programs, Reviewed per E7 2.60

Date

APPROVAL:

F. M. Pennebaker, Manager

Date

Process Technology Programs

D. E. Dooley, Director

Date

Environmental \& Chemical Process Technology Research Programs

E. J. Freed, Manager

Date

SRR DWPF/Saltstone Facility Engineering

R. E. Edwards, Manager

Date

SRR Nuclear Safety and Engineering Integration 


\section{ACKNOWLEDGEMENTS}

The following individuals are acknowledged for providing significant contributions to this task: C. J. Black, P. U. Burkhalter, J. Fawbush, D. R. Hallman, M. L. Jenkins, M. C. Lee, C. D. Nguyen, R. C. Sullivan, and D. J. Wheeler of SRNL's Shielded Cells Operations group; and L. W. Brown, C. J. Coleman, D. P. DiPrete, A. A. Ekechukwu, M. A Jones, T. L. White, and J. E. Young of SRNL's Analytical Development section. The assistance of each of these individuals is appreciated. 


\section{EXECUTIVE SUMMARY}

Tank 51 slurry sample HTF-51-15-130 was collected following sludge washing at the Tank Farm. The sample was received at SRNL and then characterized in preparation for qualification of the alternate reductant Sludge Batch 9 (SB9) flowsheet. In this characterization, densities, solids distribution, elemental constituents, anionic constituents, carbon content, and select radioisotopes were quantified. In summary, the results indicated that:

- the slurry density was $1.14 \mathrm{~g} / \mathrm{mL}$ and the supernatant density was $1.05 \mathrm{~g} / \mathrm{mL}$

- the total solids content of the slurry was $18.9 \mathrm{wt} \%$ and the insoluble solids content of the slurry was $13.7 \mathrm{wt} \%$

- the dominant elemental constituents in the slurry solids (excluding oxygen, nitrogen, and hydrogen) were iron, sodium, aluminum, manganese, mercury, and uranium, at concentrations of approximately $17,13,7,6,3$, and $3 \mathrm{wt} \%$ solids, respectively

- the dominant elemental constituents in the supernatant (excluding oxygen, nitrogen, and hydrogen) were sodium, aluminum, and sulfur, at concentrations of approximately 22000,1400 , and $270 \mathrm{mg} / \mathrm{L}$, respectively

- the dominant anions in the supernatant were nitrite, free hydroxide, and nitrate, at concentrations of approximately $0.34,0.25$, and $0.14 \mathrm{M}$, respectively

- the total inorganic carbon in the slurry was approximately $1000 \mathrm{mg} / \mathrm{kg}$ and the total organic carbon in the slurry was also approximately $1000 \mathrm{mg} / \mathrm{kg}$

- the concentration of Cs-137 in the supernatant was approximately $0.25 \mathrm{Ci} / \mathrm{gal}$

The characterization results reported in this document are consistent with expectations based upon waste type, process knowledge, and previous characterization results (those results obtained for the Tank 51 SB9 sample that was washed at SRNL [HTF-51-15-81]). 


\section{TABLE OF CONTENTS}

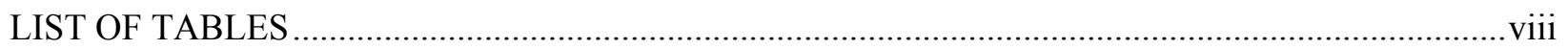

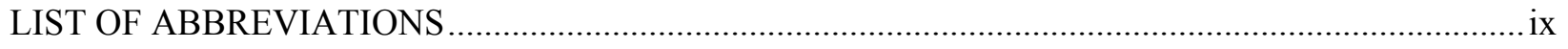

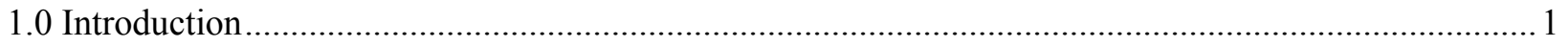

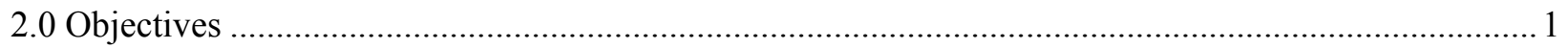

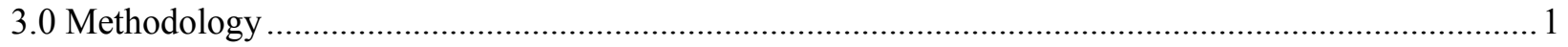

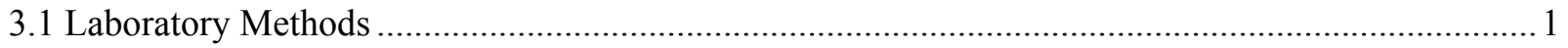

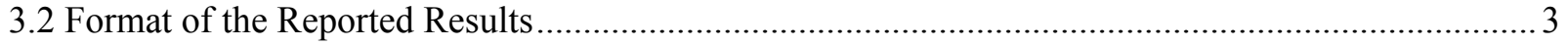

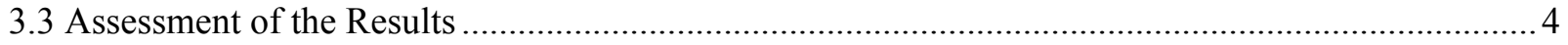

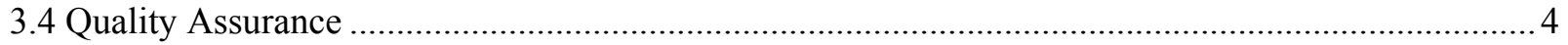

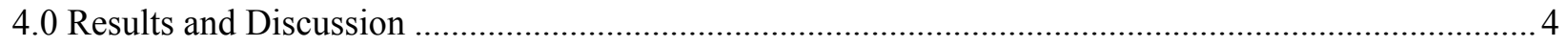

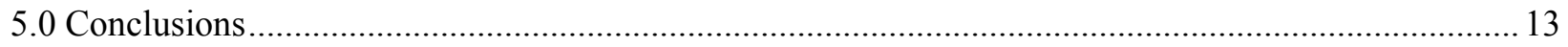

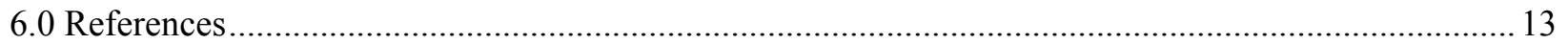




\section{LIST OF TABLES}

Table 4-1. Densities and Solids Contents ................................................................................... 5

Table 4-2. Elemental Analysis of Slurry Solids (Shading Indicates Concentrations $>0.1 \mathrm{wt} \%$ ) .............. 6

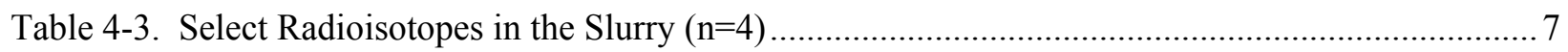

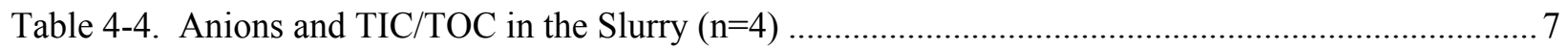

Table 4-5. Elemental Analysis of Supernatant................................................................................... 9

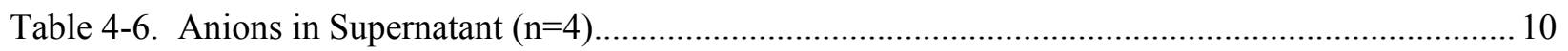

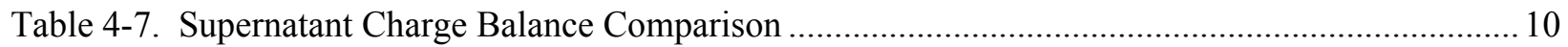

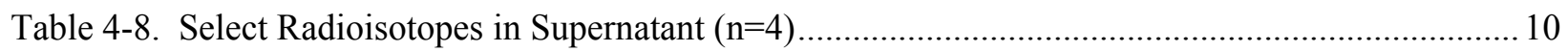

Table 4-9. Comparison of Density and Solids Measurement Results for the Tank Farm-Washed Slurry Sample (HTF-51-15-130) versus the SRNL-Washed Slurry Sample (HTF-51-15-83)..................... 11

Table 4-10. Comparison of Analytical Results for Dominant Slurry Constituents ( Elementals with Concentrations Greater than $0.1 \mathrm{wt} \%$ Solids), Slurry Oxalate, and Slurry TIC/TOC in the Tank FarmWashed Sample (HTF-51-15-130) versus the SRNL-Washed Sample (HTF-51-15-83)................... 11

Table 4-11. Comparison of Concentrations of Key Supernatant Constituents in the Tank Farm-Washed Slurry (HTF-51-15-130) versus the SRNL-Washed Slurry (HTF-51-15-83)................................... 12 


\section{LIST OF ABBREVIATIONS}

$\begin{array}{ll}\text { AD } & \text { Analytical Development } \\ \text { AR } & \text { Aqua regia } \\ \text { CVAA } & \text { Cold vapor atomic absorption } \\ \text { HM } & \text { H-Modified } \\ \text { IC } & \text { Ion chromatography } \\ \text { ICP-AES } & \text { Inductively coupled plasma atomic emission spectroscopy } \\ \text { ICP-AES-S } & \text { ICP-AES axial sulfur method } \\ \text { ICP-MS } & \text { Inductively coupled plasma mass spectrometry } \\ \text { MDL } & \text { Minimum detection limit } \\ \text { n } & \text { Number of determinations } \\ \text { PF } & \text { Peroxide fusion } \\ \text { RSD } & \text { Relative standard deviation } \\ \text { SB9 } & \text { Sludge Batch } 9 \\ \text { SRNL } & \text { Savannah River National Laboratory } \\ \text { SRR } & \text { Savannah River Remediation } \\ \text { TIC } & \text { Total inorganic carbon } \\ \text { TOC } & \text { Total organic carbon }\end{array}$




\subsection{Introduction}

A 2.9 liter sludge slurry sample was collected from Savannah River Site Tank 51 on November 10, 2015, following washing of the sludge in preparation for disposition as part of Defense Waste Processing Facility Sludge Batch 9 (SB9). The sampling depth was twelve inches below the upper surface of the waste and the sample identification number was HTF-51-15-130. The approximate temperature of the waste at the time of sampling was $30{ }^{\circ} \mathrm{C}$. The sample was submitted to SRNL for characterization purposes and for use in subsequent sludge batch qualification testing to demonstrate the alternate reductant (nitric acid/glycolic acid) flowsheet. The applicable scope of work is defined in Technical Task Request X-TTR-S-00002, Rev. $1^{1}$ and Task Technical and Quality Assurance Plan SRNL-RP-2015$00838 .^{2}$ The characterization results for the slurry sample are reported in this document.

\subsection{Objectives}

The specific objectives of the characterization were to quantify:

a) densities of the slurry and supernatant;

b) the solids distribution of the slurry (total, dissolved, insoluble, soluble, and calcined solids);

c) dominant elemental constituents in the total solids and supernatant (excluding elements oxygen, nitrogen, and hydrogen);

d) noble metals in the total solids;

e) anions in the slurry and supernatant;

f) select radioisotopes in the slurry and supernatant; and

g) total inorganic and total organic carbon in the slurry.

\subsection{Methodology}

\subsection{Laboratory Methods}

Densities: Density measurements were conducted at a temperature of $\sim 14{ }^{\circ} \mathrm{C}$. This temperature was governed by the Shielded Cells conditions at the time of the measurements. Densities were measured using weight-calibrated balances and 8-9 mL volume-calibrated plastic test tubes. Four individual slurry aliquots and four individual supernatant aliquots were utilized in the measurements. Supernatant was generated as a filtrate by passing slurry through a $0.45 \mu \mathrm{m}$ filtration membrane (note that this generation method was utilized for all of the supernatant analyses - not just those used for determining density). The density of a deionized water standard was determined along with the slurry and supernatant determinations, to demonstrate measurement accuracy.

Solids Distribution: Total solids and dissolved solids determinations were performed by driving water from slurry and supernatant aliquots (respectively) at a nominal temperature of $\sim 110^{\circ} \mathrm{C}$. Four individual slurry aliquots and four individual supernatant aliquots were utilized in the measurements. The mass of each aliquot was $\sim 3.0 \mathrm{~g}$. Insoluble and soluble solids concentrations were calculated based on the total solids and dissolved solids measurements. Calcined solids were then generated by heating the dried slurry aliquots (from the total solids measurements) to a temperature of $\sim 1100{ }^{\circ} \mathrm{C}$. One of the four 
calcined solids aliquots was compromised during the procedure and therefore excluded from the mean calcined solids concentration calculation.

Elemental Analysis of Slurry Solids: In preparation for the elemental analyses (prior to submittal), four slurry aliquots were digested by the aqua regia (AR) method and four slurry aliquots were digested by the peroxide fusion (PF) method. Note that the AR method utilized a sealed vessel to prevent loss of volatile constituents. Applicable blanks were also processed through the digestion methods, and multi-element standards were submitted along with the digest solutions, where applicable, for quality assurance purposes. The total solids mass of each sample aliquot was $\sim 0.25 \mathrm{~g}$, and the volume of each final digest solution was $100 \mathrm{~mL}$.

Inductively coupled plasma atomic emission spectroscopy (ICP-AES) was performed on both the AR and PF digest solutions, along with the applicable blanks and multi-element standard solution for quality assurance purposes. The ICP-AES measurements provided quantification of most of the elemental constituents reported in this document. The ICP-AES axial sulfur method (ICP-AES-S) was performed on the AR digest solutions for quantifying sulfur. Cold vapor atomic absorption (CVAA) spectroscopy was performed on the AR digest solutions (along with the AR blank) for the purpose of quantifying mercury. Inductively coupled plasma mass spectrometry (ICP-MS) was performed on the AR digest solutions (along with the AR blank) for the purpose of quantifying neodymium, as well as noble metals palladium, rhodium, and ruthenium. Note that noble metal silver was quantified based on the ICP-AES measurements. Dilution-correction of the results was performed by Analytical Development (AD) prior to reporting.

The elemental results determined through ICP-AES analyses were based either solely on the AR digest solutions, solely on the PF digest solutions, or on both the AR and PF digest solutions, depending on the following factors: potential for interference, magnitude of "blank values," magnitude of minimum detection limits, consistency of data, and apparent anomalies. Note that applicable digestion method(s) feeding the results is identified in the table providing the results.

The elemental results determined through ICP-MS analyses were based on sums of specific isotope results. For neodymium, the isotope results that were summed were those associated with mass numbers 143-146, 148, and 150. For rhodium, the result was based solely on the isotope associated with mass number 103. For ruthenium, the isotope results that were summed were those associated with mass numbers 101, 102, and 104. For palladium, the result was calculated utilizing fission yields and measurements based on mass numbers 105-108 and 110, per the method documented by Bibler in $2005 .^{3}$

Elemental Analysis of Supernatant: In preparation for the elemental analyses (prior to submittal), four supernatant aliquots were each diluted by a factor of $\sim 26$ (on a volume basis), using $0.16 \mathrm{M} \mathrm{HNO}_{3}$. Use of the $0.16 \mathrm{M} \mathrm{HNO}_{3}$ diluent resulted in a final solution $\mathrm{pH}$ of $\sim 2$, which was considered beneficial for minimizing loss of constituents through sorption to the walls of the sample submittal vessels and through potential precipitation reactions. An applicable "acid blank" and a multi-element standard were submitted along with the acidified/diluted supernatant, for quality assurance purposes. 
ICP-AES, ICP-AES-S, and CVAA were performed on the acidified/diluted supernatant aliquots, to quantify routine elemental constituents, sulfur, and mercury, respectively. Note that prior to the supernatant mercury measurements, AD performed permanganate-persulfate digestions on the acidified/diluted sample aliquots. Dilution-correction of the results was performed prior to reporting.

Anions in the Slurry: In preparation for the anion analyses (prior to submittal), four slurry aliquots were each diluted by a factor of $\sim 38$ (on a volume basis), using de-ionized water. The diluted slurry aliquots were agitated for a minimum of 30 seconds, and then passed through a $0.45 \mu \mathrm{m}$ filtration membrane, to remove insoluble solids. An applicable de-ionized water blank was also prepared. Ion chromatography (IC) was performed on the filtrate aliquots, to quantify bromide, chloride, fluoride, formate, nitrate, nitrite, oxalate, phosphate, and sulfate. Dilution-correction of the results was performed prior to reporting.

Anions in the Supernatant: In preparation for the anion analyses (prior to submittal), four supernatant aliquots were each diluted by a factor of $\sim 26$ (on a volume basis), using de-ionized water. IC was performed on the diluted supernatant aliquots, to quantify bromide, chloride, fluoride, formate, nitrate, nitrite, oxalate, phosphate, and sulfate. Total inorganic carbon (TIC) analyses were performed to quantify carbonate, and base titration analyses were performed to quantify free hydroxide. Aluminate was quantified based on the ICP-AES supernatant aluminum concentration, assuming $100 \%$ of the aluminum was present as aluminate. Dilution-correction of the results was performed prior to reporting.

Select Radioisotopes in the Slurry Solids: The same AR digestion method that was used for the slurry elemental analyses was utilized for preparing the slurry aliquots for the select radioisotope analyses (four slurry aliquots digested by AR plus an AR blank for quality assurance purposes). ICP-MS was performed on the AR digest solutions to quantify Tc-99, Th-232, U-233, U-234, U-235, U-236, U-238, Np-237, Pu239, and $\mathrm{Pu}-240$. Dilution-correction of the results was performed prior to reporting.

Select Radioisotopes in the Supernatant: The same acid dilution method that was used for the supernatant elemental analyses was utilized for preparing the supernatant aliquots for the select radioisotope analyses (four supernatant aliquots acidified and diluted using $0.16 \mathrm{M}$ nitric acid plus an $0.16 \mathrm{M}$ acid blank for quality assurance purposes). Gamma spectroscopy was performed on the acidified/diluted supernatant aliquots to quantify Cs-137/Ba-137m, and ICP-MS was performed to quantify Tc-99, U-235, and U-238 (these were the only radioisotopes with concentrations exceeding the minimum detection limits).

TIC and Total Organic Carbon (TOC) in the Slurry: The same water dilution method that was used for the slurry anion analyses was utilized for preparing the slurry aliquots for the TIC/TOC analyses. However, in contrast to the preparation approach for the slurry anion analyses, no filtration of the diluted slurry was performed prior to submitting the diluted slurry aliquots for the TIC/TOC analyses. This was done to assure that all insoluble and soluble carbon compounds would be measured. Dilution-correction of the results was performed prior to reporting.

\subsection{Format of the Reported Results}

Mean results, based on the average of all applicable analytical determinations, are reported in this document, along with the percent relative standard deviation (\%RSD) and the number of determinations (n) feeding each mean. \%RSD provides an indication of the measurement variation between replicate 
determinations, but is typically not an indicator of analytical accuracy. In general, the one sigma analytical uncertainty as reported by Analytical Development was 10\%, although it was sometimes lower or higher. Specifically, the one sigma analytical uncertainties reported by AD were: a) $\sim 10 \%$ for base titration, IC, ICP-AES, ICP-AES-S, ICP-MS, and TIC/TOC analyses; b) 20\% for CVAA analyses; and c) $\sim 5 \%$ for Cs-137/Ba-137m determined by gamma spectroscopy. As such, only one to two of the leading digits reported for the $\mathrm{AD}$ analysis results should be considered significant.

Note that in calculating the mean concentrations, data were not rejected if they appeared questionable, unless there was a clear anomaly impacting all constituents of a particular sample aliquot. One such case was that of one of the four PF digest solutions used in the ICP-AES measurements, for which every measured constituent concentration was about half that of the other digest solutions (both PF and AR digest solutions). Because of this anomaly, results of the anomalous PF digest solution were excluded when calculating the applicable mean concentrations.

\subsection{Assessment of the Results}

Multiple approaches were used to assess the validity of the analytical data being reported. The primary goal of this was to demonstrate that the reported results were both reasonable and consistent with expectations. Focus areas of the assessment included: a) densities and solids distribution; b) dominant constituents in the slurry solids; c) uranium and plutonium distributions; d) dominant constituents in the supernatant; e) charge balance ions in the supernatant; and e) comparisons with characterization results for the SRNL-washed Tank 51 SB9 sample. ${ }^{4}$ Discussion of the assessment approaches and results is included in Section 4.0. Note that when characterization results were compared, percent differences were calculated as follows:

$\%$ Difference $=100 \times[($ absolute value of the difference between results $) \div($ the average result $)]$

\subsection{Quality Assurance}

Standard laboratory quality assurance protocols were used to assure analytical data quality. This included use of blanks, standards, and replicate determinations.

Requirements for performing reviews of technical reports and the extent of review are established in manual E7 2.60. SRNL documents the extent and type of review using the SRNL Technical Report Design Checklist contained in WSRC-IM-2002-00011, Rev. 2.

\subsection{Results and Discussion}

Densities and solids contents are given in Table 4-1. As shown in the table, the slurry and supernatant densities are 1.14 and $1.05 \mathrm{~g} / \mathrm{mL}$, respectively. This is reasonable, given that the total solids content is $\sim 19 \mathrm{wt} \%$ and the dissolved solids content is $\sim 6 \mathrm{wt} \%$. In general terms, the amount that the slurry solids density exceeds that of water should be about three times the amount that the supernatant density exceeds that of water, since the total solids content is about three times that of the dissolved solids content. From this perspective, the densities and solids distribution are consistent with expectations.

All of the RSDs for the densities and solids content measurements were low, on the order of one percent or less, demonstrating high measurement precision and lack of any apparent shielded cells processing anomalies. 
Concentrations of the elemental constituents in the slurry solids are given in Table 4-2, with results greater than $0.1 \mathrm{wt} \%$ shaded for easy identification. (Note that this table contains analytical results for the primary elemental constituents measured by ICP-AES, sulfur by ICP-AES-S, mercury by CVAA, and neodymium and noble metals palladium, rhodium, and ruthenium by ICP-MS). As shown in the table, the dominant constituents in the solids include iron, sodium, aluminum, manganese, mercury, and uranium, with concentrations of approximately $17,13,7,6,3$, and $3 \mathrm{wt} \%$, respectively. These concentrations are consistent with expectations, given that a significant fraction of the SB9 material was H-Modified (HM) Tank 12 sludge that had been processed through aluminum dissolution.

Table 4-1. Densities and Solids Contents

\begin{tabular}{|l|c|c|}
\hline Measurement & Result & \%RSD, n \\
\hline \hline Slurry density, g/mL & 1.14 & $0.7,4$ \\
\hline Supernatant density, g/mL & 1.05 & $0.3,4$ \\
\hline Total solids, wt\% of slurry & 18.9 & $0.7,4$ \\
\hline Insoluble solids, wt\% of slurry & 13.7 & N/A \\
\hline Soluble solids, wt\% of slurry & 5.2 & N/A \\
\hline Calcined solids, wt \% of slurry & 14.7 & $1.2,3$ \\
\hline Dissolved solids, wt \% of supernatant & 6.0 & $0.4,4$ \\
\hline
\end{tabular}

Most of the RSDs for the elemental analyses were limited to ten percent or less, demonstrating normal analytical precision. In contrast, the RSDs applicable to boron, potassium, and palladium were higher, at 25,14 , and $21 \%$, respectively. These higher RSDs give an indication that the propagated analytical uncertainties associated with these three constituents are likely higher than those of the other constituents.

Concentrations of select radioisotopes in the slurry solids are given in Table 4-3, both on a mass concentration basis (wt\% solids) and a slurry activity basis (Ci/gallon slurry). As expected, U-238 and Th-232 were present at the highest mass concentrations, at $\sim 3$ and $\sim 1 \mathrm{wt} \%$, respectively. In contrast, the mass concentrations of the other radioisotopes were two to three orders of magnitude lower. On an activity basis, the $\mathrm{Pu}-239$ concentration was highest $(\sim 3 \mathrm{E}-03 \mathrm{Ci} / \mathrm{gal})$ and the Th-232 concentration $(\sim 7 \mathrm{E}-$ $07 \mathrm{Ci} / \mathrm{gal}$ ) was lowest, which was reasonable, given the relatively high specific activity of $\mathrm{Pu}-239$ and the very low specific activity of Th-232.

A comparison of the U-238 and Th-232 mass concentrations presented in Table 4-3 $(\sim 2.7$ and $\sim 0.75 \mathrm{wt} \%$, respectively) with the elemental uranium and thorium concentrations presented in Table 4-2 ( $\sim 2.6$ and $\sim 0.84 \mathrm{wt} \%$, respectively) shows relatively good agreement between the results of the ICP-MS measurements and results of the ICP-AES measurements. Specifically, the uranium results from the two methods differed by about four percent, while the thorium results differed by about $11 \%$. These differences are reasonable, given that $10 \%$ is the estimated one sigma analytical uncertainty of each of these methods.

Based on the isotopic results in Table 4-3, the calculated U-235 mass enrichment is about $1.4 \%$. This agrees well with the projected average U-235 mass enrichment for Tank 12 sludge (1.5\%), based on the waste receipt history documented in SRR's Sludge 1.5 database. In contrast, using the isotopic results in Table 4-3, the calculated ratio of $\mathrm{Pu}-240$ mass to $\mathrm{Pu}-239$ plus $\mathrm{Pu}-240$ mass is about $9 \%$. This is about $40 \%$ lower than the average ratio based on waste history receipt (per SRR's Sludge 1.5 database) however, still well within the normal range of ratios as indicated per the waste receipt history (most of the ratios fall between 6 and 16\%, based on receipt history). These comparisons provide a measure of confidence that the radioisotope concentrations in Table 4-3 are reasonable. Note that the RSDs for the 
isotopic results were limited to three percent or less, indicating high analytical precision and the absence of clear analytical anomalies.

Table 4-2. Elemental Analysis of Slurry Solids (Shading Indicates Concentrations $>0.1$ wt\%)

\begin{tabular}{|c|c|c|c|}
\hline Constituent & Digestion Method(s) & Concentration, wt \% solids & \%RSD, n \\
\hline $\mathrm{Ag}$ & AR & 7.02E-03 & $2.6,4$ \\
\hline $\mathrm{Al}$ & AR \& PF & $7.00 \mathrm{E}+00$ & $4.0,7$ \\
\hline B & $\mathrm{AR}$ & $6.80 \mathrm{E}-03$ & 25,4 \\
\hline $\mathrm{Ba}$ & AR \& PF & $5.76 \mathrm{E}-02$ & $3.6,7$ \\
\hline $\mathrm{Be}$ & AR & $3.15 \mathrm{E}-04$ & $1.3,4$ \\
\hline $\mathrm{Ca}$ & $\mathrm{AR}$ & $1.04 \mathrm{E}+00$ & $1.2,4$ \\
\hline $\mathrm{Cd}$ & $\mathrm{AR}$ & $1.51 \mathrm{E}-02$ & $3.1,4$ \\
\hline $\mathrm{Ce}$ & AR & $<2.8 \mathrm{E}-03$ & $\mathrm{~N} / \mathrm{A}$ \\
\hline Co & $\mathrm{AR}$ & $7.16 \mathrm{E}-03$ & $1.5,4$ \\
\hline $\mathrm{Cr}$ & $\mathrm{AR}$ & $7.34 \mathrm{E}-02$ & $0.9,4$ \\
\hline $\mathrm{Cu}$ & $\mathrm{AR}$ & $3.87 \mathrm{E}-02$ & $0.7,4$ \\
\hline $\mathrm{Fe}$ & AR \& PF & $1.70 \mathrm{E}+01$ & $3.8,7$ \\
\hline Gd & AR \& PF & $7.20 \mathrm{E}-02$ & $7.8,7$ \\
\hline $\mathrm{Hg}$ & $\mathrm{AR}$ & $2.60 \mathrm{E}+00$ & $3.8,4$ \\
\hline $\mathrm{K}$ & AR & $6.52 \mathrm{E}-02$ & 14,4 \\
\hline $\mathrm{La}$ & $\mathrm{AR}$ & $2.39 \mathrm{E}-02$ & $0.7,4$ \\
\hline $\mathrm{Li}$ & AR & $9.17 \mathrm{E}-02$ & $1.5,4$ \\
\hline $\mathrm{Mg}$ & $\mathrm{AR}$ & $2.16 \mathrm{E}-01$ & $0.4,4$ \\
\hline $\mathrm{Mn}$ & AR \& PF & $5.73 \mathrm{E}+00$ & $5.0,7$ \\
\hline Mo & $\mathrm{AR}$ & $1.10 \mathrm{E}-02$ & $1.4,4$ \\
\hline $\mathrm{Na}$ & AR & $1.27 \mathrm{E}+01$ & $2.9,4$ \\
\hline $\mathrm{Nd}$ & AR & $1.01 \mathrm{E}-01$ & $0.8,4$ \\
\hline $\mathrm{Ni}$ & AR \& PF & 7.42E-01 & $6.2,7$ \\
\hline $\mathrm{P}$ & $\mathrm{AR}$ & $1.66 \mathrm{E}-01$ & $1.0,4$ \\
\hline $\mathrm{Pb}$ & AR & $3.49 \mathrm{E}-02$ & $6.0,4$ \\
\hline $\mathrm{Pd}$ & AR & $1.62 \mathrm{E}-03$ & 21,4 \\
\hline $\mathrm{Rh}$ & AR & $8.66 \mathrm{E}-03$ & $1.0,4$ \\
\hline $\mathrm{Ru}$ & AR & $3.99 \mathrm{E}-02$ & $1.9,4$ \\
\hline $\mathrm{S}$ & AR & $1.64 \mathrm{E}-01$ & $4.7,4$ \\
\hline $\mathrm{Sb}$ & $\mathrm{AR}$ & $<2.1 \mathrm{E}-02$ & $\mathrm{~N} / \mathrm{A}$ \\
\hline $\mathrm{Si}$ & $\mathrm{PF}$ & $1.59 \mathrm{E}+00$ & $4.1,3$ \\
\hline $\mathrm{Sn}$ & AR & $<1.3 \mathrm{E}-02$ & $\mathrm{~N} / \mathrm{A}$ \\
\hline $\mathrm{Sr}$ & AR & $2.17 \mathrm{E}-02$ & $0.4,4$ \\
\hline $\mathrm{Th}$ & AR \& PF & $8.39 \mathrm{E}-01$ & $8.0,7$ \\
\hline $\mathrm{Ti}$ & AR & $3.23 \mathrm{E}-02$ & $0.5,4$ \\
\hline $\mathrm{U}$ & AR \& PF & $2.63 \mathrm{E}+00$ & $6.5,7$ \\
\hline $\mathrm{V}$ & $\mathrm{AR}$ & $<4.6 \mathrm{E}-04$ & $\mathrm{~N} / \mathrm{A}$ \\
\hline $\mathrm{Zn}$ & AR \& PF & $2.98 \mathrm{E}-02$ & $4.2,7$ \\
\hline $\mathrm{Zr}$ & $\mathrm{AR}$ & $2.28 \mathrm{E}-02$ & $7.0,4$ \\
\hline
\end{tabular}


Table 4-3. Select Radioisotopes in the Slurry $(n=4)$

\begin{tabular}{|l|c|c|c|}
\hline Isotope & $\begin{array}{c}\text { Mass Concentration, } \\
\text { wt\% solids }\end{array}$ & $\begin{array}{c}\text { Activity Concentration, } \\
\text { Ci/gal slurry }\end{array}$ & \%RSD \\
\hline \hline Tc-99 & $1.80 \mathrm{E}-03$ & $2.49 \mathrm{E}-04$ & 2.0 \\
\hline Th-232 & $7.53 \mathrm{E}-01$ & $6.73 \mathrm{E}-07$ & 1.4 \\
\hline U-233 & $7.53 \mathrm{E}-04$ & $5.94 \mathrm{E}-05$ & 3.0 \\
\hline U-234 & $8.15 \mathrm{E}-04$ & $4.15 \mathrm{E}-05$ & 2.2 \\
\hline U-235 & $4.02 \mathrm{E}-02$ & $7.09 \mathrm{E}-07$ & 1.8 \\
\hline U-236 & $2.17 \mathrm{E}-03$ & $1.15 \mathrm{E}-06$ & 2.7 \\
\hline $\mathrm{U}-238$ & $2.74 \mathrm{E}+00$ & $7.52 \mathrm{E}-06$ & 1.8 \\
\hline Np-237 & $2.67 \mathrm{E}-03$ & $1.54 \mathrm{E}-05$ & 2.4 \\
\hline Pu-239 & $6.34 \mathrm{E}-03$ & $3.21 \mathrm{E}-03$ & 1.8 \\
\hline Pu-240 & $6.31 \mathrm{E}-04$ & $1.17 \mathrm{E}-03$ & 1.0 \\
\hline
\end{tabular}

Concentrations of anions, TIC, and TOC in the slurry are given in Table 4-4. As shown in table, the dominant anions included nitrite and nitrate, at concentrations of $\sim 12,000$ and $\sim 7,000 \mathrm{mg} / \mathrm{kg}$, respectively. In contrast, oxalate was present at $\sim 4,000 \mathrm{mg} / \mathrm{kg}$, sulfate was present at $\sim 600 \mathrm{mg} / \mathrm{kg}$, and chloride, fluoride, and formate were present at significantly lower concentrations $(\sim 70, \sim 30$, and $\sim 50 \mathrm{mg} / \mathrm{kg}$, respectively). Note that the chloride and fluoride concentrations are likely biased high, as indicated by comparably high concentrations measured in the blank. Neither bromide nor phosphate was quantified, each being present at concentrations less than the minimum detection limits. Both TIC and TOC were quantified at concentrations of $\sim 1,000 \mathrm{mg} / \mathrm{kg}$. Note that the RSDs were on the order of ten percent or less, with exception of that for formate, which was forty percent. This relatively high RSD gives an indication that the total propagated analytical uncertainty for the formate result is likely higher than those of the other results.

Table 4-4. Anions and TIC/TOC in the Slurry $(n=4)$

\begin{tabular}{|l|c|c|}
\hline Constituent & $\begin{array}{c}\text { Concentration, } \\
\text { mg/kg slurry }\end{array}$ & \%RSD \\
\hline \hline Bromide & $<1.04 \mathrm{E}+03$ & N/A \\
\hline Chloride & $6.56 \mathrm{E}+01^{*}$ & 1.9 \\
\hline Fluoride & $3.28 \mathrm{E}+01^{*}$ & 1.9 \\
\hline Formate & $4.95 \mathrm{E}+01$ & 40 \\
\hline Nitrate & $7.03 \mathrm{E}+03$ & 0.8 \\
\hline Nitrite & $1.16 \mathrm{E}+04$ & 1.7 \\
\hline Oxalate & $3.74 \mathrm{E}+03$ & 1.7 \\
\hline Phosphate & $<1.04 \mathrm{E}+03$ & N/A \\
\hline Sulfate & $5.74 \mathrm{E}+02$ & 1.5 \\
\hline TIC & $9.70 \mathrm{E}+02$ & 12 \\
\hline TOC & $1.10 \mathrm{E}+03$ & 8.0 \\
\hline
\end{tabular}

*The chloride and fluoride concentrations are likely biased high, as indicated by comparably high concentrations measured in the blank.

Concentrations of elemental constituents in the supernatant are given in Table 4-5. As shown in the table, sodium was the most dominant constituent with a concentration of $\sim 22,000 \mathrm{mg} / \mathrm{L}$, corresponding to a molarity of just slightly less than one $(0.96 \mathrm{M})$. The second and third most dominant constituents were aluminum and sulfur, with concentrations of $\sim 1400$ and $\sim 270 \mathrm{mg} / \mathrm{L}$, respectively. Potassium and 
mercury came next, with concentrations of $\sim 100$ and $\sim 40 \mathrm{mg} / \mathrm{L}$, respectively. In contrast, concentrations of all the other elemental constituents were significantly lower than $40 \mathrm{mg} / \mathrm{L}$ or less than the minimum detection limits. The other detectable constituents included boron, calcium, iron, zinc, magnesium, and manganese.

The relative dominance of sodium, aluminum, sulfur, potassium, and mercury in the supernatant is consistent with expectations, based on anticipated elemental abundances, elemental solubilities, and previous characterization experiences. Note that RSDs for the sodium, aluminum, sulfur, and potassium results were minimal ( 0.4 to $2.1 \%$ ), indicating high analytical uncertainty. In contrast, the RSD for the mercury result was higher at $14 \%$, although still within the range of normal RSDs. Still higher RSDs were observed for the iron, calcium, zinc, and magnesium results $(20,35,59$, and $88 \%$, respectively), likely indicating elevated propagated analytical uncertainties for these results.

Concentrations of anions in the supernatant are given in Table 4-6. As shown in the table, the most dominant anions were nitrite, free hydroxide, and nitrate, at concentrations of approximately $0.34,0.25$, and $0.14 \mathrm{M}$, respectively. Less dominant, although still detectable, were carbonate, aluminate, oxalate, and sulfate, at concentrations of approximately $0.054,0.053,0.053$, and $0.0069 \mathrm{M}$, respectively. When converted to a mass concentration basis, the relative quantities of anions in the supernatant mirror those measured in the slurry (Table 4-4), where nitrite was most dominant, followed by nitrate, oxalate, carbonate (as TIC), and sulfate. Concentrations of the other anions (bromide, chloride, fluoride, formate, and phosphate) in the supernatant were all less than the minimum detection limits. Note that the RSDs for the supernatant anion results were all relatively low $(0.4$ to $\sim 7 \%)$, indicating good analytical precision.

A charge balance comparison was performed to demonstrate consistency between the concentrations of primary supernatant cations and the concentrations of primary supernatant anions. For this comparison, the primary cations were assumed to be $\mathrm{Na}^{+}$and $\mathrm{K}^{+}$, and the primary anions were assumed to be $\mathrm{NO}_{2}{ }^{-}$, $\mathrm{OH}^{-}, \mathrm{NO}_{3}{ }^{-}, \mathrm{CO}_{3}{ }^{2-}$, and $\mathrm{Al}(\mathrm{OH})_{4}^{-}$. This assumption is based upon the analytical results obtained for the respective supernatant analyses (ICP-AES results for aluminum, potassium, and sodium; IC results for nitrate, nitrite, oxalate, and sulfate; base titration for free hydroxide; and TIC for carbonate).

In this comparison, molar concentrations of the respective ions were converted to equivalent concentrations, based on the applicable ionic charge (an ion charge of one for sodium, potassium, aluminate, free hydroxide, nitrate, and nitrite - and an ion charge of two for carbonate oxalate, and sulfate). The sums of the equivalent concentrations for the cations and anions were then calculated and compared to one another, to determine consistency.

Results of the charge balance comparison are given in Table 4-7. As shown in the table, the total equivalent concentration for the cations was calculated to be $0.959 \mathrm{eq} / \mathrm{L}$, while the total equivalent concentration for the anions was calculated to be $1.015 \mathrm{eq} / \mathrm{L}$. The difference between these values is $\sim 6 \%$, a value which indicates very good consistency, as it is well below the total anticipated sampling and analysis uncertainty. (Neglecting processing uncertainty, the estimated one sigma analytical uncertainty for an individual determination is approximately $10 \%$ ).

Concentrations of select radioisotopes in the supernatant are given in Table 4-8. As shown in the table, the concentrations varied over nine orders of magnitude, from a low of $\sim 2 \mathrm{E}-10 \mathrm{Ci} / \mathrm{gal}$ for U-235 to a high of $\sim 2 \mathrm{E}-01 \mathrm{Ci} / \mathrm{gal}$ for $\mathrm{Cs}-137$. This is consistent with expectations, given the low solubility and low specific activity of the uranium isotope versus the high solubility and high specific activity of the cesium isotope. Note that the RSDs were all less than ten percent, indicating good measurement precision. 
Table 4-5. Elemental Analysis of Supernatant

\begin{tabular}{|c|c|c|}
\hline Constituent & Concentration, mg/L & \%RSD, n \\
\hline $\mathrm{Ag}$ & $<6.0 \mathrm{E}-01$ & N/A \\
\hline $\mathrm{Al}$ & $1.44 \mathrm{E}+03$ & $0.4,4$ \\
\hline $\mathrm{B}$ & $1.37 \mathrm{E}+01$ & $6.9,4$ \\
\hline $\mathrm{Ba}$ & $<1.8 \mathrm{E}-01$ & N/A \\
\hline $\mathrm{Be}$ & $<5.4 \mathrm{E}-02$ & $\mathrm{~N} / \mathrm{A}$ \\
\hline $\mathrm{Ca}$ & $7.46 \mathrm{E}+00$ & 35,4 \\
\hline $\mathrm{Cd}$ & $<8.2 \mathrm{E}-01$ & $\mathrm{~N} / \mathrm{A}$ \\
\hline $\mathrm{Ce}$ & $<2.4 \mathrm{E}+00$ & N/A \\
\hline Co & $<6.4 \mathrm{E}-01$ & N/A \\
\hline $\mathrm{Cr}$ & $<9.3 \mathrm{E}-01$ & N/A \\
\hline $\mathrm{Cu}$ & $<6.1 \mathrm{E}-01^{\mathrm{a}}$ & $\mathrm{N} / \mathrm{A}$ \\
\hline $\mathrm{Fe}$ & $1.30 \mathrm{E}+00$ & 20,4 \\
\hline Gd & $<3.1 \mathrm{E}+00$ & $\mathrm{~N} / \mathrm{A}$ \\
\hline $\mathrm{Hg}$ & $3.88 \mathrm{E}+01$ & 14,4 \\
\hline $\mathrm{K}$ & $9.80 \mathrm{E}+01$ & $2.1,4$ \\
\hline $\mathrm{La}$ & $<3.7 \mathrm{E}-01$ & N/A \\
\hline $\mathrm{Li}$ & $<4.5 \mathrm{E}+00$ & $\mathrm{~N} / \mathrm{A}$ \\
\hline $\mathrm{Mg}$ & $4.66 \mathrm{E}-01$ & 88,4 \\
\hline $\mathrm{Mn}$ & $1.00 \mathrm{E}-01^{b}$ & $3.6,2$ \\
\hline Mo & $<1.8 \mathrm{E}+00$ & $\mathrm{~N} / \mathrm{A}$ \\
\hline $\mathrm{Na}$ & $2.20 \mathrm{E}+04$ & $0.5,4$ \\
\hline $\mathrm{Ni}$ & $<5.7 \mathrm{E}+00$ & $\mathrm{~N} / \mathrm{A}$ \\
\hline $\mathrm{P}$ & $<8.7 \mathrm{E}+00$ & N/A \\
\hline $\mathrm{Pb}$ & $<8.8 \mathrm{E}+00$ & $\mathrm{~N} / \mathrm{A}$ \\
\hline $\mathrm{S}$ & $2.74 \mathrm{E}+02$ & $0.8,4$ \\
\hline $\mathrm{Sb}$ & $<1.8 \mathrm{E}+01$ & $\mathrm{~N} / \mathrm{A}$ \\
\hline $\mathrm{Si}$ & $<3.5 \mathrm{E}+00^{\mathrm{c}}$ & N/A \\
\hline $\mathrm{Sn}$ & $<1.1 \mathrm{E}+01$ & N/A \\
\hline $\mathrm{Sr}$ & $<5.4 \mathrm{E}-02$ & N/A \\
\hline Th & $<3.2 \mathrm{E}+00$ & N/A \\
\hline $\mathrm{Ti}$ & $<8.7 \mathrm{E}+00$ & N/A \\
\hline $\mathrm{U}$ & $<1.7 \mathrm{E}+01$ & N/A \\
\hline $\mathrm{V}$ & $<3.6 \mathrm{E}-01$ & $\mathrm{~N} / \mathrm{A}$ \\
\hline $\mathrm{Zn}$ & $5.68 \mathrm{E}-01$ & 59,4 \\
\hline $\mathrm{Zr}$ & $<5.3 \mathrm{E}-01$ & N/A \\
\hline
\end{tabular}

${ }^{\text {a }}$ The $\mathrm{Cu}$ result in the table is based on three measurements which were less than the minimum detection limit (MDL). The fourth measurement was a detectable concentration $(0.73 \mathrm{mg} / \mathrm{L})$ that exceeded the MDL identified in the table.

${ }^{\mathrm{b}}$ The Mn result in the table is based on two measurements which exceeded the MDL. The other two Mn measurements were lower than the MDL and lower than the result in the table (their concentrations were $<0.075$ $\mathrm{mg} / \mathrm{L})$.

${ }^{\mathrm{c}}$ The Si result in the table is based on three measurements which were less than the MDL. The fourth measurement was a detectable concentration $(4.4 \mathrm{mg} / \mathrm{L})$ that exceeded the MDL identified in the table. 
Table 4-6. Anions in Supernatant $(n=4)$

\begin{tabular}{|l|c|c|}
\hline Anion & Concentration, M & \%RSD \\
\hline \hline Aluminate & $5.32 \mathrm{E}-02$ & 0.4 \\
\hline Bromide & $<1.6 \mathrm{E}-02$ & N/A \\
\hline Carbonate & $5.44 \mathrm{E}-02$ & 3.4 \\
\hline Chloride & $<7.2 \mathrm{E}-03$ & N/A \\
\hline Fluoride & $<1.3 \mathrm{E}-02$ & N/A \\
\hline Formate & $<5.7 \mathrm{E}-03$ & N/A \\
\hline Free hydroxide & $2.52 \mathrm{E}-01$ & 6.6 \\
\hline Nitrate & $1.40 \mathrm{E}-01$ & 1.5 \\
\hline Nitrite & $3.42 \mathrm{E}-01$ & 1.4 \\
\hline Oxalate & $5.27 \mathrm{E}-02$ & 1.2 \\
\hline Phosphate & $<2.7 \mathrm{E}-03$ & N/A \\
\hline Sulfate & $6.86 \mathrm{E}-03$ & 2.6 \\
\hline
\end{tabular}

Table 4-7. Supernatant Charge Balance Comparison

\begin{tabular}{|l|c|c|c|}
\hline \multirow{2}{*}{ Ion } & \multicolumn{2}{|c|}{ Equivalent Concentration, eq/L } & \multirow{2}{*}{$\begin{array}{c}\% \\
\text { Difference }\end{array}$} \\
\cline { 2 - 3 } & Cationic & Anionic & \\
\hline $\mathrm{Na}^{+}$ & 0.956 & N/A & \\
\hline $\mathrm{K}^{+}$ & 0.003 & N/A & \\
\hline $\mathrm{Al}(\mathrm{OH})_{4}{ }^{-}$ & N/A & 0.053 & \\
\hline $\mathrm{CO}_{3}{ }^{2-}$ & N/A & 0.109 & \\
\hline $\mathrm{OH}^{-}$ & N/A & 0.252 & \\
\hline $\mathrm{NO}_{3}{ }^{-}$ & N/A & 0.140 & \\
\hline $\mathrm{NO}_{2}{ }^{-}$ & N/A & 0.342 & \\
\hline $\mathrm{C}_{2} \mathrm{O}_{4}{ }^{2-}$ & N/A & 0.105 & \\
\hline $\mathrm{SO}_{4}{ }^{2-}$ & N/A & 0.014 & \\
\hline & $\Sigma=0.959$ & $\Sigma=1.015$ & 5.7 \\
\hline
\end{tabular}

Table 4-8. Select Radioisotopes in Supernatant $(n=4)$

\begin{tabular}{|l|c|c|}
\hline Isotope & $\begin{array}{c}\text { Concentration, } \\
\text { Ci/gal supernatant }\end{array}$ & \%RSD \\
\hline \hline Tc-99 & $3.11 \mathrm{E}-05$ & 1.6 \\
\hline Cs-137 & $2.47 \mathrm{E}-01$ & 3.3 \\
\hline Ba-137m & $2.34 \mathrm{E}-01$ & 3.3 \\
\hline U-235 & $2.08 \mathrm{E}-10$ & 1.7 \\
\hline U-238 & $2.05 \mathrm{E}-09$ & 9.0 \\
\hline
\end{tabular}

Comparisons of the analytical results reported for the current sample (the Tank Farm-Washed sample, HTF-51-15-130) versus those reported for the previous sample (the SRNL-Washed Tank 51 SB9 sample, HTF-51-15-83) are given in Tables 4-9, 4-10, and 4-11 below. Note that Table 4-9 addresses the density and solids content measurements; Table 4-10 addresses dominant slurry elementals $(>0.1 \mathrm{wt} \%)$, slurry oxalate, and slurry TIC/TOC; and Table 4-11 addresses key supernatant elementals and supernatant anions. 
Table 4-9. Comparison of Density and Solids Measurement Results for the Tank Farm-Washed Slurry Sample (HTF-51-15-130) versus the SRNL-Washed Slurry Sample (HTF-51-15-83)

\begin{tabular}{|l|c|c|c|}
\hline $\begin{array}{l}\text { Measured Property } \\
\text { and the Reporting Units }\end{array}$ & $\begin{array}{c}\text { Tank Farm-Washed } \\
\text { (HTF-51-15-130) }\end{array}$ & $\begin{array}{c}\text { SRNL-Washed } \\
\text { (HTF-51-15-83) }\end{array}$ & $\begin{array}{c}\text { \% } \\
\text { Difference }\end{array}$ \\
\hline \hline Slurry density, g/mL & 1.14 & 1.15 & 1 \\
\hline Supernatant density, g/mL & 1.05 & 1.04 & 1 \\
\hline Total solids, wt\% of slurry & 18.9 & 19.6 & 4 \\
\hline Insoluble solids, wt\% of slurry & 13.7 & 14.6 & 6 \\
\hline Soluble solids, wt\% of slurry & 5.2 & 5.0 & 4 \\
\hline Calcined solids, wt\% of slurry & 14.7 & 15.3 & 4 \\
\hline Dissolved solids, wt\% of supernatant & 6.0 & 5.8 & 3 \\
\hline
\end{tabular}

As shown in Table 4-9, the density and solids content measurements for the current slurry sample are quite consistent with the measurements for the previous slurry sample, with differences ranging from one to six percent. Note that the greatest difference $(6 \%)$ applied to insoluble solids results, which are calculated values subject to propagated uncertainty that is a function of multiple terms. Nonetheless, a maximum of $6 \%$ deviation is very good, given the limitations of the Shielded Cells processing and weighing facilities.

Table 4-10. Comparison of Analytical Results for Dominant Slurry Constituents ( Elementals with Concentrations Greater than 0.1 wt\% Solids), Slurry Oxalate, and Slurry TIC/TOC in the Tank Farm-Washed Sample (HTF-51-15-130) versus the SRNL-Washed Sample (HTF-51-15-83)

\begin{tabular}{|c|c|c|c|c|}
\hline Constituent & $\begin{array}{c}\text { Concentration } \\
\text { Reporting Units }\end{array}$ & $\begin{array}{c}\text { Tank Farm-Washed } \\
\text { (HTF-51-15-130) }\end{array}$ & $\begin{array}{l}\text { SRNL-Washed } \\
\text { (HTF-51-15-83) }\end{array}$ & $\begin{array}{c}\% \\
\text { Difference } \\
\end{array}$ \\
\hline $\mathrm{Al}$ & \multirow{14}{*}{ wt $\%$ solids } & $7.00 \mathrm{E}+00$ & $6.95 \mathrm{E}+00$ & 1 \\
\hline $\mathrm{Ca}$ & & $1.04 \mathrm{E}+00$ & $1.03 \mathrm{E}+00$ & 1 \\
\hline $\mathrm{Fe}$ & & $1.70 \mathrm{E}+01$ & $1.80 \mathrm{E}+01$ & 6 \\
\hline $\mathrm{Hg}$ & & $2.60 \mathrm{E}+00$ & $3.12 \mathrm{E}+00$ & 18 \\
\hline $\mathrm{Mg}$ & & $2.16 \mathrm{E}-01$ & $2.30 \mathrm{E}-01$ & 6 \\
\hline $\mathrm{Mn}$ & & $5.73 \mathrm{E}+00$ & $6.03 \mathrm{E}+00$ & 5 \\
\hline $\mathrm{Na}$ & & $1.27 \mathrm{E}+01$ & $1.22 \mathrm{E}+01$ & 4 \\
\hline $\mathrm{Nd}$ & & $1.01 \mathrm{E}-01$ & $1.04 \mathrm{E}-01$ & 3 \\
\hline $\mathrm{Ni}$ & & $7.42 \mathrm{E}-01$ & $7.68 \mathrm{E}-01$ & 3 \\
\hline $\mathrm{P}$ & & $1.66 \mathrm{E}-01$ & $2.03 \mathrm{E}-01$ & 20 \\
\hline $\mathrm{S}$ & & $1.64 \mathrm{E}-01$ & $1.76 \mathrm{E}-01$ & 7 \\
\hline $\mathrm{Si}$ & & $1.59 \mathrm{E}+00$ & $1.73 \mathrm{E}+00$ & 8 \\
\hline $\mathrm{Th}$ & & $8.39 \mathrm{E}-01$ & 8.01E-01 & 5 \\
\hline $\mathrm{U}$ & & $2.63 \mathrm{E}+00$ & $3.09 \mathrm{E}+00$ & 16 \\
\hline Oxalate & \multirow{3}{*}{$\mathrm{mg} / \mathrm{kg}$ slurry } & $3.74 \mathrm{E}+03$ & $3.88 \mathrm{E}+03$ & 4 \\
\hline TIC & & $9.70 \mathrm{E}+02$ & $1.04 \mathrm{E}+03$ & 7 \\
\hline TOC & & $1.10 \mathrm{E}+03$ & $9.31 \mathrm{E}+02$ & 17 \\
\hline
\end{tabular}


As shown in Table 4-10, agreement between the slurry constituent results of the current sample versus those of the previous sample is generally very good, with differences ranging from one to twenty percent and an average difference of $\sim 8 \%$. Given the breadth of constituents that are being compared and the distribution of the differences, it is clear that the differences are consistent with expectations based on an estimated two sigma analytical uncertainty of $\sim 20 \%$ (which is the value applicable to most of these data, as reported by $\mathrm{AD}$ - note that the estimated two sigma analytical uncertainty for mercury determinations is typically $\sim 40 \%$ ).

Table 4-11. Comparison of Concentrations of Key Supernatant Constituents in the Tank FarmWashed Slurry (HTF-51-15-130) versus the SRNL-Washed Slurry (HTF-51-15-83)

\begin{tabular}{|c|c|c|c|c|}
\hline Constituent & $\begin{array}{c}\text { Concentration } \\
\text { Reporting Units }\end{array}$ & $\begin{array}{c}\text { Tank Farm-Washed } \\
\text { (HTF-51-15-130) }\end{array}$ & $\begin{array}{c}\text { SRNL-Washed } \\
\text { (HTF-51-15-83) }\end{array}$ & $\begin{array}{c}\% \\
\text { Difference }\end{array}$ \\
\hline $\mathrm{Al}$ & \multirow{10}{*}{ Molarity } & $5.32 \mathrm{E}-02$ & $4.89 \mathrm{E}-02$ & 8 \\
\hline $\mathrm{K}$ & & $2.51 \mathrm{E}-03$ & $2.99 \mathrm{E}-03$ & 17 \\
\hline $\mathrm{Na}$ & & $9.56 \mathrm{E}-01$ & $9.94 \mathrm{E}-01$ & 4 \\
\hline $\mathrm{S}$ & & $8.55 \mathrm{E}-03$ & $8.49 \mathrm{E}-03$ & 1 \\
\hline Carbonate & & $5.44 \mathrm{E}-02$ & $9.87 \mathrm{E}-02$ & 58 \\
\hline Free hydroxide & & $2.52 \mathrm{E}-01$ & $2.47 \mathrm{E}-01$ & 2 \\
\hline Nitrate & & $1.40 \mathrm{E}-01$ & $1.38 \mathrm{E}-01$ & 1 \\
\hline Nitrite & & $3.42 \mathrm{E}-01$ & $2.96 \mathrm{E}-01$ & 14 \\
\hline Oxalate & & $5.27 \mathrm{E}-02$ & $5.43 \mathrm{E}-02$ & 3 \\
\hline Sulfate & & $6.86 \mathrm{E}-03$ & $6.70 \mathrm{E}-03$ & 2 \\
\hline $\mathrm{Hg}$ & $\mathrm{mg} / \mathrm{L}$ & $3.88 \mathrm{E}+01$ & $8.78 \mathrm{E}+01$ & 77 \\
\hline
\end{tabular}

As shown in Table 4-11, agreement between the supernatant constituent results of the current sample versus those of the previous sample is generally very good, with two major exceptions (one for carbonate and one for mercury). Neglecting the carbonate and mercury results, the differences observed between the other supernatant results ranged from one to seventeen percent, with an average difference of $\sim 6 \%$, which is considered good for these types of analyses.

In contrast, for carbonate and mercury, the differences were significantly greater, at 58 and $77 \%$, respectively. These differences are not thought to be due to unusually high analytical uncertainties instead they are attributed to differences associated with the manner that the samples were processed in the laboratory and inherent changes that can impact the final carbonate and mercury concentrations.

Specifically, the higher supernatant carbonate concentration in the SRNL-washed sample is likely due to additional absorbed carbon dioxide that reacted with the sodium hydroxide in solution to form additional carbonate. Due to the small size of the slurry sample that was washed in the laboratory (as opposed to large slurry volume washed in Tank 51), and due to the vigorous agitation that was employed in the laboratory to assure effective washing, it is likely that additional carbon dioxide was introduced into the SRNL-washed sample, leading to the higher final carbonate concentration.

With respect to mercury (as in the case of carbonate), the higher supernatant concentration in the previous sample was likely due to processing differences incurred during washing, although the exact source of the increase is more difficult to pinpoint, as there are several potential causes, due to the complex distribution of mercury compounds within high level waste sludge slurries. 
The first possibility is rooted in the expectation that some portion of the mercury in the slurry exists in the form of elemental liquid mercury, which tends to be distributed heterogeneously within the solid-phase sludge matrix and is therefore subject to sampling heterogeneity. During vigorous agitation as was performed during the SRNL-washing, there is the potential for miniscule liquid mercury beads to be liberated from the solid phase sludge matrix. Introduction of such beads into supernatant aliquots that are diluted and then submitted for analysis is one possible means for raising supernatant phase mercury concentrations. In the case of the SRNL-washed slurry, supernatant was decanted from the settled insoluble solids (as opposed to being generated through filtration), so the possibility exists that carryover of one or more miniscule entrained mercury beads could have occurred.

Another possibility is tied to chemical reactions and the impact of kinetics during washing and equilibration. Included among such chemical reactions are changes in the solubility of mercury that can occur during washing (as the hydroxide concentration is reduced), as well as mercury speciation changes that are associated with the changed chemical conditions. One thing is clear - washing of the slurry that was performed in the laboratory occurred over a much shorter time period than that associated with the washing performed at the Tank Farm. Due to this difference, there is the expectation that the chemistry of the Tank Farm sample had a much greater chance of having reached equilibrium conditions (or nearequilibrium conditions) than the laboratory washed sample. For complex constituents such as mercury, these differences in equilibrium would be expected to have measureable effects.

\subsection{Conclusions}

The characterization results for the Tank 51 Alternate Reductant SB9 sample are believed to be sound, and are considered consistent with expectations based on waste type, process knowledge, and previous characterization data.

\subsection{References}

$1 \quad$ Fellinger, T. L., “Technical Task Request: Shielded Cells Qualification Run - Nitric/Glycolic Flowsheet," Savannah River Remediation, X-TTR-S-00002, Revision 1, October 2015.

2 Pareizs, J. M. and D. P. Lambert, "Task Technical and Quality Assurance Plan for Sludge Batch 9 Shielded Cells Qualification Run - Nitric/Glycolic Flowsheet," Savannah River National Laboratory, SRNL-RP-2015-00838, December 2015.

3 Bibler, N. E., "Measuring and Predicting Fission Product Noble Metals in Savannah River Site High Level Waste Sludges,” Savannah River National Laboratory, WSRC-TR-2005-00098, April 2005. 


\section{Distribution:}

H. P. Boyd, 704-27S

J. M. Bricker, 704-S

L. W. Brown, 773-A

T. B. Brown, 773-A

M. E. Cercy, 773-42A

C. J. Coleman, 773-A

T. E. Colleran, 773-67A

J. S. Contardi, 704-56H

J. A. Crenshaw, 703-46A

D. A. Crowley, 773-43A

D. P. DiPrete, 773-41A

D. E. Dooley, 773-A

R. E. Edwards, 766-H

A. A. Ekechukwu, 773-41A

A. P. Fellinger. $773-42 \mathrm{~A}$

T. L. Fellinger, 766-H

S. D. Fink, 773-A

E. J. Freed, 704-S

J. M. Gillam, 766-H

B. A. Hamm, 766-H

C. C. Herman, 773-A

D. T. Hobbs, 773-A

E. N. Hoffman, 999-W

E. W. Holtzscheiter, 766-H

J. E. Hyatt, 773-A

J. F. Iaukea, 704-27S

S. T. Isom, 773-67A

M. A. Jones, 773-A

K. M. Kostelnik, 773-42A

P. R. Jackson, DOE-SR, 703-46A

V. Jain, 766-H

D. P. Lambert, 999-W

B. B. Looney, 773-42A

C. J. Martino, 999-W

D. A. McGuire, 773-42A

R. T. McNew, 766-H

T. O. Oliver, 773-42A

J. M. Pareizs, 773-A

F. M. Pennebaker, 773-42A

J. W. Ray, 704-27S

P. J. Ryan, 704-26S

M. A. Rios-Armstrong, 766-H

H. B. Shah, 766-H

D. C. Sherburne, 249-8H

G. N. Smoland, 773-42A

C. Sudduth, 707-7E

J. R Vitali, 704-30S

A. L. Washington, 773-42A

T. L. White, 773-A

A. W. Wiggins, 241-168H

W. R. Wilmarth, 773-A

J. E. Young, 773-41A

Records Administration (EDWS) 